\title{
PENGARUH MOTIVASI KERJA, PELATIHAN DAN KEPUASAN KERJA TERHADAP PRESTASI KERJA PEGAWAI PADA KANTOR KECAMATAN MAJAULENG KABUPATEN WAJO
}

\author{
Andi Ardasanti \\ STIE Pelita Buana Makassar (ardasantiandi@gmail.com)
}

\begin{abstract}
ABSTRAK
Penelitian ini bertujuan untuk menguji dan menganalisis pengaruh Motivasi kerja, pelatihan dan kepuasan kerjasecara terhadap Prestasi Kerja Pegawai Pada Kantor Kecamatan Majauleng Kabupaten Wajo, baik secara parsial maupun simultan.

Pendekatan penelitian ini didasarkan pada model desain penelitian sebagai survey yang bersifat korelasional dengan menggunakan pendekatan kuantitatif.Penelitian korelasional berupaya menjelaskan ada tidaknya hubungan atau pengaruh di antara berbagai variabel berdasarkan besar kecilnya koefisien korelasi.

Populasi dalam penelitian ini adalah seluruh pegawai padaKantor Kecamatan Majauleng Kabupaten Wajo sebanyak 72 orang pegawai. Pengambilan sampel penelitian ini dilakukan dengan menggunakan teknik sampel jenuh atau sensus yaitu semua populasi di jadikan sebagai sampel. Teknik analisa data kuantitatif yang diperoleh dari hasil kuesioner dengan menggunakan analisis regresi linier berganda (multiple regression analysis).

Hasil penelitian menunjukkan bahwa Secara parsial maupun simultan, motivasi, pelatihan dan kepuasan kerja berpengaruh secara positif dan signifikan terhadap Prestasi kerja pegawai pada Kantor Kecamatan Majauleng Kabupaten Wajo
\end{abstract}

\begin{abstract}
Work motivation, training and job satisfaction towards Employee Work Achievement at Majauleng District Office in Wajo Regency, both partially and simultaneously.

This study uses a survey research design model that uses correlational using a quantitative approach. Correlational research discusses explaining that there is no relationship or relationship between various variables based on the size of the coefficient in question.

The population in this study were all employees at the Majauleng District Office in Wajo District as many as 72 employees. Sampling of this study was carried out using saturated samples or census techniques, namely all populations were made as samples. Quantitative data analysis techniques obtained from the results of questionnaires using multiple linear regression analysis (multiple regression analysis).

The results showed that partially simultaneous, motivation, training and positive job satisfaction were significant and significant for employee work performance at Majauleng District Office, Wajo District.
\end{abstract}

\section{PENDAHULUAN}

\section{Latar Belakang}

Peningkatan prestasi kerja pegawai perusahaan/organisasi dapat dilakukan 
dengan beberapa cara misalnyamelalui pelatihan, pendidikan dan adanya hubungan kerja yang baik dengan semua tim yang ada pada organisasi tersebut.

Pelatihan yang di ikuti pegawai akan memberikan kontribusi terhadap peningkatan prestasi kerjanya dan memberikan kepuasan kerja bagi yang bersangkutan. Kepuasan kerja adalah suatu penilaian dari karyawan mengenai sejauh mana pekerjaannya secara keseluruhan mampu memuaskan kebutuhannya. Dapat di katakan pula bahwa kepuasan kerja merupakan perasaan pekerja terhadap pekerjaannya (Asa'ad, 1995)

Motivasi adalah kekuatan, baik dari dalam maupun dari luaryang mendorong seseorang untuk mencapai tujuan tertentu yang telah ditetapkan sebelumnya.Motivasi merupakan salah satu peran yang harus dilakukan oleh pemimpin terhadap bawahannya. Pemimpin memotivasi karyawan untuk menghasilkan Prestasi Kerja yang ditetapkan, memberikan dukungan, membantu, dan mengarahkan karyawan dalam menyelesaikan pekerjaan mereka, seorang pemimpin harus mempunyai cara yang tepat untuk memotivasi karyawannya agar mencapai prestasi kerja yang tinggi.

Berdasarkan pengamatan penulis berbagai upaya telah dilakukan selama ini untuk meningkatkan prestasi kerja pegawai Kantor Kecamatan Majauleng Kabupaten Wajo melalui diklatpim IV, on the job training, pendidikan dan pelatihan, Latpim III, Latpim II dan sebagainya tetapi kurang membawa hasil yang memadai. Hal ini disebabkan oleh karena hampir semua peserta hanya berorientasi pada kebutuhan sesaat, yakni kebutuhan akan penjenjangan atau promosi jabatan bukannya mengarah kepada pendalaman tugas-tugas sebagai unsur yang sangat menentukan tujuan usaha organisasi tersebut. Misalnya peningkatan kualitas kerja, peningkatan Prestasi Kerja dan produktivitas kerja, peningkatan prestasi karyawan dan kemajuan perusahaan secara keseluruhan.

\section{Rumusan Masalah}

Berdasarkan uraian dalam latar belakang di atas, maka permasalahan yang akan diajukan dalam penelitian ini adalah:

1. Apakah Motivasi kerja, pelatihan dan kepuasan kerja berpengaruh secara parsial terhadap Prestasi Kerja Pegawai Pada Kantor Kecamatan Majauleng Kabupaten Wajo? 
2. Apakah Motivasi kerja, pelatihan dan kepuasan kerja berpengaruh secara simultanterhadap Prestasi Kerja Pegawai Pada Kantor Kecamatan Majauleng Kabupaten Wajo?

3. Variabel manakah yang dominan pengaruhnya terhadap Prestasi Kerja Pegawai Pada Kantor Kecamatan Majauleng Kabupaten Wajo?

\section{KAJIAN PUSTAKA}

\section{Motivasi}

Amstrong (1990) memberikan defenisi motivasi sebagai sesuatu yang membuat orang bertindak atau berperilaku dalam cara-cara tertentu. Lebih jauh dikemukakan motivasi adalah sesuatu yang menggerakkan orang untuk mencapai rasa memiliki tujuan bersama dengan memastikan bahwa sejauh mungkin keinginan dan kebutuhan organisasi serta keinginan dan kebutuhan anggotanya berada dalam keadaan yang harmonis atau seimbang.

Teori Maslow yang dikenal dengan teori kebutuhan sebagaimana dalam bukunya Bruce ( 1994) melihat motivasi selalu berkaitan dengan kebutuhan yang secara hirarki mulai dari yang terendah sampai tertinggi

Teori Abraham Maslow mengasumsikan bahwa manusia pada prinsipnya berusaha memenuhi kebutuhan yang paling pokok sebelum berusaha memenuhi kebutuhannya yang paling tinggi. Apabila suatu kebutuhan sudah terpenuhi kebutuhannya yang paling tinggi. Apabila suatu hubungan sudah terpenuhi maka daya motivasinya akan berhenti, misalnya apabila seorang memutuskan bahwa upah yang diterima dari majikannya atau organisasi dimana ia bekerja sudah dianggap cukup tinggi, maka uang tidak lagi mempunyai daya motivasi dan akan beralih kepada kebutuhan yang belum terpenuhi.

Porter dan Gibson (1992 : 93) telah melakukan penelitian dan mengasumsikan bahwa kebutuhan fisiologis sudah dipenuhi dengan cukup baik para manajer dan ia menggantikannya dengan kebutuhan yang lebih tinggi tingkatannya yang disebut otonomi. Labih jauh porter menjelaskan bahwa yang dimaksud dengan otonomi adalah kepuasan orang dengan kesempatan mengambil keputusan secara bebas, menetapkannya tujuan dan bekerja tanpa pengawasan yang ketat. 


\section{Pelatihan}

Pelatihan merupakan proses mengubah perilaku pegawai baik sikap, kemampuan, keahlian, maupun pengetahuan dalam suatu arah guna meningkatkan tujuan operasional yang berorientasi dalam jangka pendek untuk memecahkan masalah terkini dan persiapan jangka panjang untuk menghadapi tantangan di masa mendatang. Simamora (2007:140) menyatakan usaha memperbaiki kualitas sumber daya manusia melalui pendidikan dan pelatihan, mencegah organisasi berhubungan dengan pegawai-pegawai yang tidak kompeten terutama dalam masalah disiplin dan pegawai-pegawai yang memiliki kecakapan yang telah ketinggalan zaman.

Pelatihan merupakan usaha organisasi yang sengaja dilakukan untuk meningkatkan Prestasi Kerja sekarang dan yang akan datang dengan meningkatkan kemampuan. Nitisemito (2005:86) memberikan definisi pendidikan dan pelatihan adalah suatu kegiatan dari organisasi yang bermaksud untuk dapat memperbaiki dan mengembangkan sikap tingkah laku, keterampilan dan pengetahuan dari para pegawai yang sesuai dengan keinginan dari organisasi yang bersangkutan.

\section{Konsep Kepuasan Kerja}

Kepuasan kerja karyawan merupakan penilaian atau cerminan dari perasaan pekerjaannya. Hal tersebut terlihat dari sikap positif yang ditunjukkan pekerja terhadap pekerjaannya serta segala sesuatu yang dihadapi lingkungan kerjanya. Menurut Scehermerhorn (2008) kepuasan kerja adalah suatu tingkatan perasaan yang positif atau negatif tentang beberapa aspek dari pekerjaan, situasi kerja, dan hubungan antar sesama rekan kerja.

Locke (2009) mengatakan bahwa kepuasan kerja merupakan suatu perasaan senang atau emosi positif yang muncul dari penilaian positif seseorang akan pekerjaan atau pengalaman bekerjanya. Walaupun kepuasan kerja didefinisikan sebagai keadaan emosi seperti juga halnya dengan kepuasan atas aspek-aspek kehidupan lainnya.

Kepuasan kerja merupakan konstruk sikap yang merefleksikan evaluasi seseorang atas pekerjaannya. Kepuasan kerja umumnya diukur melalui "single-shot" dalam survey yang bersifat retrospektif yang sesungguhnya hanya baik untuk menangkap aspek kognitif dari suatu pekerjaan dan kurang mampu menangkap pengalaman-pengalaman afektif dari pekerjaan. 
Kepuasan kerja adalah keadaan emosional yang menyenangkan atau tidak menyenangkan dengan mana para karyawan memandang pekerjaan mereka. Kepuasan kerja mencerminkan perasaan seseorang terhadap pekerjaannya yang tampak dalam sikap positif karyawan terhadap pekerjaan dan segala sesuatu yang dihadapi di lingkungan kerjanya.

Kepuasan kerja merupakan bagian yang integral dari keberhasilan suatu organisasi. Kepuasan kerja menggambarkan perasaan yang dirasakan oleh pekerja akan pekerjaannya. Kepuasan kerja sebagai keadaan dimana pekerja menyenangi pekerjaannya. Kepuasan kerja sebagai afeksi atau respon emosional terhadap berbagai aspek dari suatu pekerjaan, yang menyangkut perasaan positif maupun negatif seorang pekerja atas pekerjaannya. Menurut definisi ini, seseorang dapat saja merasa puas atas satu atau beberapa aspek dari pekerjaannya.

\section{Prestasi Kerja Pegawai}

Prestasi Kerja Pegawai(job performance) mencakup sejumlah hasil yang tidak lain merupakan manifestasi kerja yang dilakukan oleh pegawai atau organisasi yang biasanya digunakan sebagai dasar penilaian atas pekerjaan atau organisasi kerja. Prestasi Kerja merupakan tindakan-tindakan atau pelaksanaan kerja yang dapat diukur (Seimour, dalam Susiati, 2007).

Dharma (2008, dalam Susiati 2007) mendefinisikan Prestasi Kerja sebagai sesuatu yang dikerjakan atau produk/ jasa yang dihasilkan atau diberikan oleh seseorang kepada sekelompok orang.Sedangkan Stoner (2006) mendefinisikan Prestasi Kerja sebagai kuantitas dan kualitas pekerjaan yang dihasilkan oleh individu, kelompok atau organisasi.

Prestasi Kerja yang berbeda antara pegawai satu dengan pegawai yang lain secara garis besar menurut Marat (dalam Susiati 2007) dipengaruhi oleh dua hal yaitu : a) faktor individu, dan b) faktor situasi. Dijelaskan bahwa Prestasi Kerja yang dihasilkan oleh para pegawai tersebut berbeda karena adanya faktor - faktor individu yang berbeda seperti misalnya adanya perbedaan kemampuan fisik, motivasi dan faktor - faktor individual lainnya.

Hal yang sama menurut Siagian (2009) bahwa Prestasi Kerja seseorang dipengaruhi oleh kondisi fisiknya. Seseorang yang memiliki kondisi 
yangmempunyai daya tahan tubuh yang tinggi yang pada gilirannya tercermin pada kegairahan bekerja dengan tingkat produktivitas yang tinggi, dan sebaliknya. Di samping itu, Prestasi Kerja individu juga berhubungan dengan kemampuan yang hams dimiliki oleh individu agar ia berperan dalam organisasi.

\section{Kerangka Konseptual}

Berdasarkan latar belakang, rumusan masalah, maka dibawah ini ditunjukkan kerangka konsep penelitian ini, yaitu:

\section{Gambar Kerangka Konsep Penelitian}

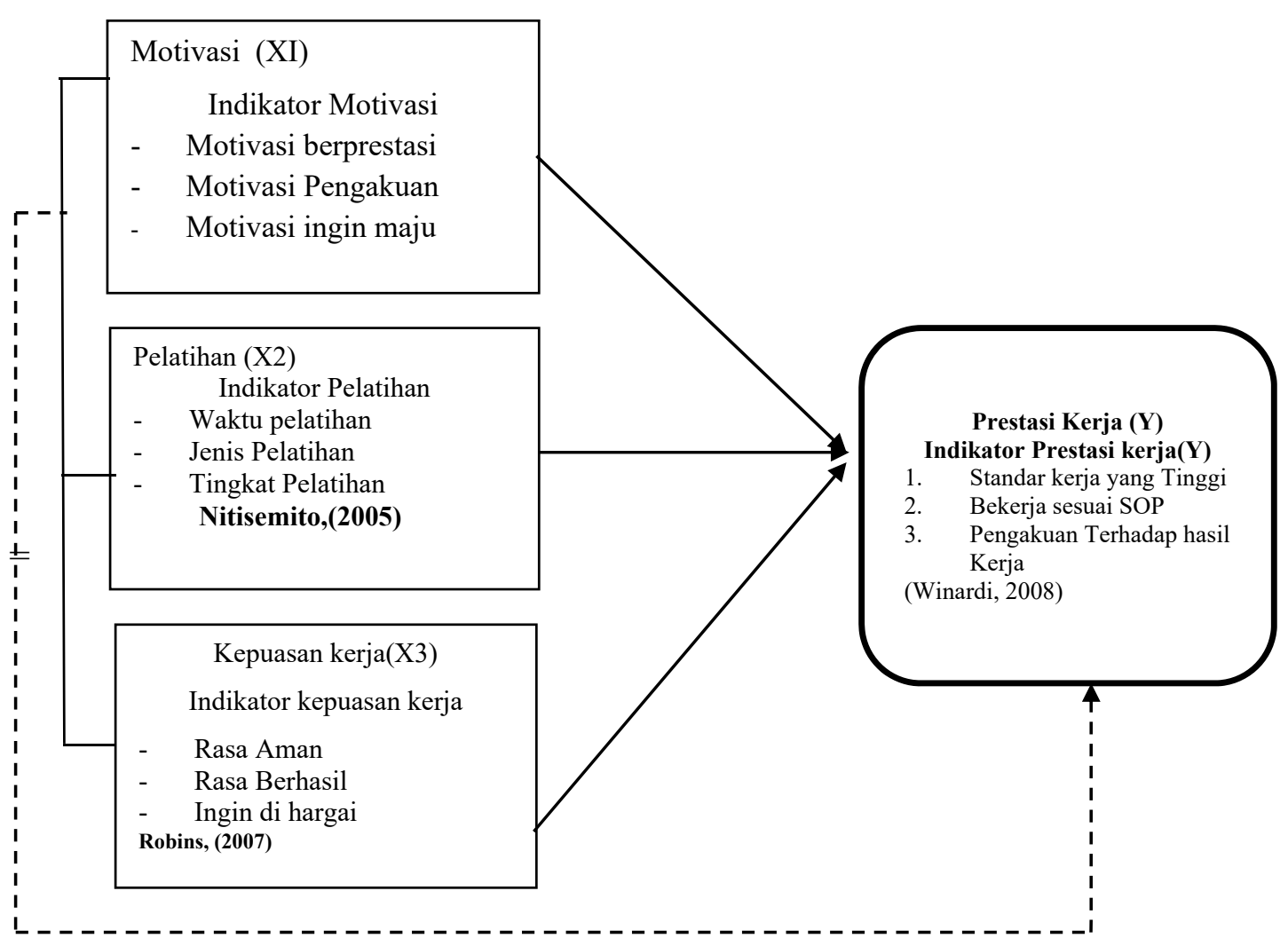

\section{Hipotesis}

Dengan melihat kerangka pikir di atas, maka penulis mengajukan hipotesisSebagaiberikut:

1. Motivasi kerja, pelatihan dan kepuasan kerja secara parsial berpengaruh terhadap Prestasi Kerja Pegawai Kantor Kecamatan Majauleng Kabupaten Wajo. 
2. Motivasi kerja, pelatihan dan kepuasan kerja secara simultan berpengaruh terhadap Prestasi Kerja Pegawai Kantor Kecamatan Majauleng Kabupaten Wajo.

3. Motivasi kerja merupakan faktor yang dominan pengaruhnya terhadap Prestasi Kerja Pegawai Kantor Kecamatan Majauleng Kabupaten Wajo.

\section{METODE PENELITIAN}

\section{Desain dan Pendekatan Penelitian}

Pendekatan penelitian ini didasarkan pada model desain penelitian sebagai survey yang bersifat korelasional dengan menggunakan pendekatan kuantitatif.Penelitian korelasional berupaya menjelaskan ada tidaknya hubungan atau pengaruh di antara berbagai variabel berdasarkan besar kecilnya koefisien korelasi.

Dalam penelitian ini, variabel yang mempunyai keterhubungan adalah motivasi kerja, pelatihan dan kepuasan kerja. Variabel yang mempunyai keterhubungan inilah menjadi model survey yang didesain membahas tentang hal yang mempengaruhi prestasi kerja pegawai.

\section{Populasi dan Sampel}

Populasi adalah wilayah generalisasi yang terdiri atas obyek/subjek yang mempunyai kuantitas dan karakteristik tertentu yang ditetapkan oleh peneliti untuk dipelajari dan kemudian ditarik kesimpulannya.Populasi dalam penelitian ini adalah seluruh pegawai padaKantor Kecamatan Majauleng Kabupaten Wajo sebanyak 72 orang pegawai.

Pengambilan sampel penelitian ini dilakukan dengan menggunakan teknik sampel jenuh atau sensus yaitu semua populasi di jadikan sebagai sampel.

Dengan demikian, jumlah sampel yang diteliti dalam penelitian ini adalah sebanyak 72 orang pegawai.

\section{Teknik Analisa Data}

Dalam penelitian ini menggunakan analisis regresi berganda dikarenakan terdapat lebih dari satu variabel independensebagai berikut:

$Y=a+b 1 X 1+b 2 X 2+b 3 X 3+e$

Dimana:

$\mathrm{Y} \quad=$ Prestasi kerja

a $\quad=$ konstanta 
$\mathrm{X}_{1} \quad=$ Motivasi kerja

$\mathrm{X}_{2} \quad=$ pelatihan

$\mathrm{X}_{3}=$ kepuasan kerja

$b_{1}, b_{2}, b_{3},,=$ Koefisien pengaruh

e $\quad=$ Kesalahan Prediksi

Selanjutnya untuk mengetahui pengaruh variabel bebas yaitu:motivasi kerja $\left(\mathrm{X}_{1}\right)$,pelatihan $\left(\mathrm{X}_{2}\right)$, dan kepuasan $\operatorname{kerja}\left(\mathrm{X}_{3}\right)$, terhadap variabelterkait yaitu Prestasi Kerja (Y) secara bersama-sama, maka dilakukan uji F.

\section{HASIL PENELITIAN}

\section{Analisis Regresi Berganda}

Pengujian hipotesis dilakukan dengan menggunakan teknik regresi. Hasil pengolahan data dapat dilihat pada tabel berikut:

Tabel 1

Hasil Regresi Berganda

\begin{tabular}{|l|c|c|c|}
\hline \multicolumn{1}{|c|}{ Model } & $\mathrm{B}$ & $\mathrm{T}$ & $\mathrm{P}(\mathrm{sig})$ \\
\hline Constant & 0,003 & 0,002 & 0.998 \\
Motivasi $\left(\mathrm{X}_{1}\right)$, & 0,375 & 4,624 & 0.000 \\
Pelatihan $\left(\mathrm{X}_{2}\right)$ & 0,343 & 3,129 & 0.003 \\
Kepuasan kerja $\left(\mathrm{X}_{3}\right)$ & 0,290 & 2,603 & 0.011 \\
\hline
\end{tabular}

Sumber : Data diolah, 2018

Dari tabel di atas diperoleh persamaan regresi

$$
\hat{\mathbf{y}}=0,003+0,375 X_{1}+0,343 X_{2}+0,290 X_{3}
$$

\section{a. Uji F (Uji Simultan)}

Pada tabel 5.2 pengujian secara simultan (uji F), dimaksudkan untuk mengetahui apakah variabel motivasi, pelatihan dan kepuasan kerja secara bersamasama memiliki pengaruh terhadap Prestasi kerja. 
Tabel 2

Hasil Uji F

\begin{tabular}{|l|r|r|r|r|c|}
\hline \multicolumn{1}{|c|}{ Model } & $\begin{array}{c}\text { Sum of } \\
\text { Squars }\end{array}$ & Df & $\begin{array}{r}\text { Mean } \\
\text { square }\end{array}$ & F & P \\
\hline Regression & 2656.578 & 3 & 885.526 & 335,843 & 0,000 \\
Residual & 179.297 & 68 & 2.637 & & \\
Total & 2835.875 & 71 & & & \\
\hline
\end{tabular}

Sumber : Data primer diolah, 2018

Berdasarkan tabel 5.2, didapatkan nilai F statistik sebesar 335,843dengan nilai signifikansi 0,000 lebih kecil dari 0,05, maka dapat diketahui bahwa secara simultan ada pengaruh signifikan antara motivasi, pelatihan dan kepuasan kerja terhadap Prestasi kerja pada Kantor Kecamatan Majauleng Kabupaten Wajo.

\section{b. Uji t (Uji Parsial)}

Pengujian ini bertujuan untuk menguji pengaruh variabel bebas (motivasi, pelatihan dan kepuasan kerja) berpengaruh signifikan atau tidak terhadap Prestasi kerja pada Kantor Kecamatan Majauleng Kabupaten Wajo pada tingkat signifikansi $\alpha=5$ persen secara terpisah atau parsial. Berikut hasil pengujian hipotesis uji t:

Tabel 3

Hasil Uji Parsial

\begin{tabular}{|l|c|c|c|}
\hline \multicolumn{1}{|c|}{ Model } & $\mathrm{B}$ & $\mathrm{T}$ & $\mathrm{P}(\mathrm{sig})$ \\
\hline Constant & 0,003 & 0,002 & 0.998 \\
Motivasi $\left(\mathrm{X}_{1}\right)$, & 0,375 & 4,624 & 0.000 \\
Pelatihan $\left(\mathrm{X}_{2}\right)$ & 0,343 & 3,129 & 0.003 \\
Kepuasan kerja $\left(\mathrm{X}_{3}\right)$ & 0,290 & 2,603 & 0.011 \\
\hline
\end{tabular}

Berdasarkan tabel 3 di atas dapat disimpulkan sebagai berikut:

1) Pengaruh motivasi kerja terhadap Prestasi kerja pada Kantor Kecamatan Majauleng Kabupaten Wajo berdasarkan tabel di atas diperoleh nilai signifikansi sebesar $0,000<0,05$, maka disimpulkan $\mathrm{H} 1$ diterima, artinya motivasi berpengaruh positif terhadap Prestasi kerja pada Kantor Kantor Kecamatan Majauleng Kabupaten Wajo 
2) Pengaruh pelatihan terhadap Prestasi kerja pada Kantor Kecamatan Majauleng Kabupaten Wajo berdasarkan tabel di atas diperoleh nilai signifikansi sebesar $0,003<0,05$, maka disimpulkan $\mathrm{H} 1$ diterima, artinya pelatihan berpengaruh positif terhadap Prestasi kerja pada Kantor Kantor Kecamatan Majauleng Kabupaten Wajo

3) Pengaruh kepuasan kerja terhadap Prestasi kerja pada Kantor Kecamatan Majauleng Kabupaten Wajo berdasarkan tabel di atas diperoleh nilai signifikansi sebesar $0,011<0,05$, maka disimpulkan H1 diterima, artinya motivasi kerja berpengaruh positif terhadap Prestasi kerja. pada Kantor Kecamatan Majauleng Kabupaten Wajo

\section{Koefisien Determinasi $\left(\mathbf{R}^{2}\right)$}

Koefisien determinasi $\left(\mathrm{R}^{2}\right)$ pada intinya mengukur seberapa jauh kemampuan model dalam menerangkan variasi variabel dependennya.Nilai $\mathrm{R}^{2}$ yang mendekati satu berarti variabel-variabel independennya memberikan hampir semua informasi yang dibutuhkan untuk memprediksi variasi variabel dependen (Ghozali, 2006). Menurut ahli dalam Ghozali (2006) menganjurkan untuk menggunakan nilai adjusted $\mathrm{R}^{2}$ untuk mengukur sejauh mana kemampuan model dalam menerangkan variasi-variabel independennya. Hal ini dikarenakan nilai adjusted $\mathrm{R}^{2}$ dapat naik atau turun apabila satu variabel independen ditambahkan ke dalam model.

Hasil perhitungan koefisien determinasi adjusted $\left(\mathrm{R}^{2}\right)$ pada Kantor Kecamatan Majauleng Kabupaten Wajo dapat dilihat pada Tabel 5.4 berikut:

Tabel 4

Hasil Perhitungan Koefisien Determinasi $\left(\mathrm{R}^{2}\right)$

\begin{tabular}{|l|r|r|r|c|}
\hline \multirow{2}{*}{ Model } & \multicolumn{4}{|c|}{} \\
\cline { 2 - 5 } & $\mathrm{R}$ & R Square & Adjusted R Square & $\begin{array}{c}\text { Std. Error of the } \\
\text { Estimate }\end{array}$ \\
\hline 1 & .968 & .937 & .934 & 11.62380 \\
\hline
\end{tabular}

Berdasarkan output SPSS pada table 4 di atas tampak bahwa dari hasil perhitungan diperoleh nilai koefisien determinasi $\left(\mathrm{R}^{2}\right)$ pada sebesar 0,937 , hal ini 
berarti koefisien determinasi pengaruh motivasi $\left(\mathrm{X}_{1}\right)$, pelatihan $\left(\mathrm{X}_{2}\right)$, dan kepuasan kerja $\left(\mathrm{X}_{3}\right)$ terhadap Prestasi kerja $(\mathrm{Y})$ sebesar 0,937atau 93.7\% variansi Prestasi kerja $(\mathrm{Y})$ dipengaruhi oleh motivasi $\left(\mathrm{X}_{1}\right)$, pelatihan $\left(\mathrm{X}_{2}\right)$, dan kepuasan kerja $\left(\mathrm{X}_{3}\right)$. Sedangkan $6,3 \%$ dipengaruhi oleh faktor lain di luar model ini.

\section{SIMPULAN DAN SARAN}

\section{Simpulan}

Berdasarkan hasil penelitian dan pembahasan yang telah dikemukakan di atas dapat ditarik beberapa kesimpulan sebagai berikut :

1. Secara parsial motivasi, pelatihan dan kepuasan kerja berpengaruh secara positif dan signifikan terhadap Prestasi kerja Kantor Kecamatan Majauleng Kabupaten Wajo. Ini berarti bahwa peningkatan motivasi, pelatihan dan kepuasan kerja mampu meningkatkan Prestasi kerja

2. Secara simultan menunjukkan bahwa variabel motivasi $\left(\mathrm{X}_{1}\right)$, pelatihan $\left(\mathrm{X}_{2}\right)$, dan kepuasan kerja $\left(\mathrm{X}_{3}\right)$ berpengaruh terhadap Prestasi kerja $(\mathrm{Y})$ yang berarti bahwa peningkatan motivasi, pelatihan dan kepuasan kerja akan mempengaruhi peningkatan Prestasi kerja sebesar 93,7\%

3. Secara parsial menunjukkan bahwa variabel motivasi berpengaruh dominan terhadap Prestasi kerja, hal ini menunjukkan bahwa semakin besar motivasi akan semakin meningkatkan Prestasi kerja pada Kantor Kecamatan Majauleng Kabupaten Wajo

\section{DAFTAR PUSTAKA}

As'ad, Moch. 1998. Psikologi Industri. Yogyakarta. Liberty

Arep, Ishak, dan Tanjung Hendri, 2003, Manajemen Motivasi, PT Gramedia Media

Saran Indonesia, Jakarta

Collins, Jim, 2001, Good to Great, Harper Business, New York, NY.

Dale, Margaret, A., 2003, The Art of HRD, Developing Management Skills,

Meningkatkan Kemampuan anajemen, Edisi Bahasa Indonesia, PT

Bhuana Ilmu Populer, Jakarta.

Gybson. ,1996, Organisasi Perilaku, Struktur, Proses, jilid 2, Erlangga, Bandung, Hasibuan H Malayu S P. 1995. Manajemen Sumber Daya Manusia. Jakarta: 
Gunung Agung

Mathis,RL. \& Jackson, JH., 2002, Manajamen Sumber Daya Manusia, PT.

Salemba Emban Patria, Jakarta

Nitisemito, Alex. 2002. Manajemen Personalia. Jakarta: Ghalia Indonesia

Robbins, S.P., 2003, Perilaku Organisasi, Edisi Indonesia, Indeks Kelompok Gramedia,

Robbins, S.P., dan Judge, T.A., 2007, Perilaku Organisasi, Ed. 12, Terjemah.,Salemba Empat, Jakarta

Simamora. Manajemen SDM, Sekolah Tinggi Ilmu Ekonomi YKPN, Yogyakarta. 2004

Simamora, Bilson, 2004, Panduan Riset Perilaku Konsumen, Jakarta: PT Gramedia Pustaka Utama

Siagian,SP..Manajamen Sumber Daya Manusia. Bumi Aksara. Jakarta. 2003

Suharyadi, dan Purwanto, 2004, Statistiaka: Untuk Ekonomi dan Keuangan Modern, Buku II, Jakarta: Salemba Empat

Sujianto, A.E, 2007, Aplikasi Statistik dengan SPSS Untuk Pemula, Cetakan Pertama, Jakarta, Prestasi Pustaka Publisher

Welch, Jack, stright from the gut, Bussines pluss 